\title{
Effects of Orally Administered Caffeine on Cellular Response in Protein Energy-malnourished Neonatal Rat Brain
}

\author{
GRIFFITH E. QUINBY, JR., YILDIZ BATIRBAYGIL, ${ }^{1}$ ARTHUR D. HARTMAN, AND \\ TETSUO NAKAMOTO \\ Departments of Pediatrics [G.E.Q.] and Physiology [G.E.Q., Y.B., A.D.H., T.N.], Louisiana State University \\ Medical Center, New Orleans, Louisiana 70119
}

\begin{abstract}
The purpose of this study was to determine the effects of caffeine on growing rats and how protein energy malnutrition can modify these potential effects. Caffeine (1,3,7-trimethylxanthine) is not only the most commonly consumed, neurally active stimulant in our daily lives, but it is widely used in the management of apnea in the premature neonate. One group of dams $(20 \%)(n=6)$ was begun on a $20 \%$ protein diet ad libitum. The second group $(6 \%)(n=4)$ was begun on a $6 \%$ protein diet. A third group $(20 \%+C)(n=4)$ was pair-fed to group 1 $(20 \%)$ with the $20 \%$ protein diet, but beginning on day 3 the pups received $10 \mathrm{mg} / \mathrm{kg}$ body weight of caffeine via intragastric feeding needle every other day. The fourth group $(6 \%+C)(n=5)$ was pair-fed with group $2(6 \%)$ with the $6 \%$ protein diet and the pups received $10 \mathrm{mg} / \mathrm{kg}$ of caffeine in the same manner as the $20 \%+C$ group from day 3. Although the $6 \%$ protein diet was associated with the expected reduced body and brain growth, there were no additional growth alterations associated with caffeine administration in either the $20 \%$ or $6 \%$ diet groups. This growth failure was accompanied by the expected reductions in total whole brain DNA, RNA, protein, and cholesterol content regardless of whether caffeine was received or not. Effects of caffeine which were similar in both diet groups included an increase in brain RNA content and concentration and an increase in the RNA/DNA ratio. However, there were differential effects of caffeine seen depending on diet group assignment. These included an increase in brain DNA content and concentration in the $6 \%$ protein group only. Furthermore the protein/DNA ratio, an index of mean cell size, was increased in the $20 \%$ plus caffeine group and decreased in the $6 \%$ plus caffeine group. The present data and our previous work with theophylline on brain development (22) indicate that methylxanthine administration produces differential effects depending on dietary intake. (Pediatr Res 19: 71-74, 1985)
\end{abstract}

Caffeine (1,3,7-trimethylxanthine) is not only the most commonly consumed, neurally active stimulant in our daily lives, but also is widely used in the management of apnea in the premature neonate $(3)$. Doses of $10 \mathrm{mg} / \mathrm{kg} /$ day produce $15-20$

Received March 19, 1984; accepted June 27, 1984.

Correspondence may be sent to Griffith E. Quinby, Jr., Department of Physiology, LSU Medical Center, 1100 Florida Ave., New Orleans, LA 70119.

${ }^{1}$ Present address: Hacettepe University Medical Center Ankara, Turkey. Supported by a fellowship grant from the World Health Organization. $\mathrm{mg} /$ liter serum concentrations (3). Cerebrospinal fluid levels of caffeine have been shown to be essentially equivalent to serum levels (25). Presumably, caffeine exerts its antiapneic effect by direct stimulation of central respiratory activity (26). In addition, caffeine stimulates smooth muscle, dilates systemic blood vessels, constricts cerebral blood vessels, alters glucose homeostasis and produces diuresis (11). Recently, we found (22) that a related xanthine derivative, theophylline (1,3-dimethylxanthine), added to the maternal diet affects not only the growth and development of the body and brain of the suckling newborn, but also the dietary and drug effects on brain tissues are closely related.

Many of the pathological conditions common in neonatal intensive care units (e.g. gastrointestinal anomalies or prolonged respiratory disorders) are associated with significant protein energy malnutrition. These infants often are given some form of methylxanthine therapy before achieving optimum nutrition. Some evidence suggests that protein energy malnutrition may alter organ sensitivity to drugs $(8,27)$, and thus alter a drug's efficacy and its therapeutic index. Caffeine-induced growth retardation in neonatal rats can be prevented by hypercaloric sucrose supplementation (6). This and our recent finding that the cellular responses to theophylline can be influenced by nutritional status led to the present study. We gave caffeine directly to the newborns rather than providing it in the maternal diet, since this approach more closely simulates the clinical situation. The purpose of this study was to determine the effects of caffeine on growing rats and how protein energy malnutrition can modify these potential effects.

\section{MATERIALS AND METHODS}

Nineteen timed pregnant rats, obtained from a commercial breeder (Holtzman Co., Madison, WI), were maintained on a 12-h light/dark cycle and fed laboratory chow and water ad libitum. At term, litters delivered within an 8 -h period were combined and designated day 1 ; eight pups were randomly assigned to each dam. Because no nutritional differences can be attributed to the sex of the animal in early life (18), pup assignment was made without regard to the sex of pups. The dams were then randomly divided into four groups. One group (20\%) $(n=6)$ was begun on a $20 \%$ protein diet ad libitum. The second group $(6 \%)(n=4)$ was begun on a $6 \%$ protein diet. The 20 and $6 \%$ protein diets were isoenergetic, with the energy differences made up by addition of dextrose and dextrin (Table 1) (18). The source of protein was casein. A third group $(20 \%+C)(n=4)$ was pair-fed to group $1(20 \%)$ with the $20 \%$ protein diet, but beginning on day 3 the pups received $10 \mathrm{mg} / \mathrm{kg}$ body weight of caffeine (dissolved in $0.1 \mathrm{ml}$ of physiological saline solution) via intragastric feeding needle every other day. The fourth group 
$(6 \%+C)(n=5)$ was pair-fed with group $2(6 \%)$ with the $6 \%$ protein diet and the pups received $10 \mathrm{mg} / \mathrm{kg}$ of caffeine in the same manner as $20 \%+\mathrm{C}$ group from day 3 . The pups in groups $1(20 \%)$ and $2(6 \%)$ received $0.1 \mathrm{ml}$ of physiological saline solution on the same days in a similar manner. Pups were weighed every other day; the dams' food intake was recorded daily.

On day 15 , the pups were killed by decapitation. The brain was rapidly removed, weighed, and frozen at $-20^{\circ} \mathrm{C}$ until analyzed. Whole brains were homogenized in $3 \mathrm{ml}$ water in the cold with a Teflon pestle homogenizing apparatus (A. H. Thomas, Philadelphia, PA). An $0.5-\mathrm{ml}$ aliquot was used to determine cholesterol content (4). Another $0.5-\mathrm{ml}$ aliquot was diluted to a final volume of $5 \mathrm{ml}$ and rehomogenized for DNA, RNA, and protein assays. DNA and RNA were determined by the method of Prasad et al. (21) and protein by the method of Lowry et al. (13). We performed statistical analyses using multiple comparison analysis of variance (Student-Newman-Keuls) on an Apple II microcomputer (Apple Corp., Cupertino, CA), with $p<0.05$ being considered significant.

\section{RESULTS}

There was no significant effect of caffeine on the growth rates of the 20 and $6 \%$ groups. The malnourished pups were significantly smaller than the normally nourished pups from day 5 to the completion of the study at day 15 (Table 2). Normally nourished dams consumed $32.01 \pm 1.83 \mathrm{~g}$ daily, while the normally nourished dams in the caffeine group consumed 30.60 $\pm 4.86 \mathrm{~g}$ daily. The malnourished groups consumed $18.71 \pm$ 3.77 and $19.35 \pm 2.42 \mathrm{~g}$, respectively, a significant increase.

No difference in brain weight was attributable to caffeine intake in the $20 \%+\mathrm{C}$ and $6 \%+\mathrm{C}$ groups (Table 3 ), but brains in the $20 \%$ group were significantly larger than the $6 \%$ group.

Brain cell number, as estimated by total DNA per brain, was decreased significantly in the $6 \%$ group compared to the $20 \%$ group (Table 4). In the $6 \%$ protein groups, the total DNA content

Table 1. Diet composition (in grams)

\begin{tabular}{lcc}
\hline & 20\% protein & $6 \%$ protein \\
\hline Casein & 200 & 60 \\
Dextrose & 192 & 267 \\
Sucrose & 178 & 172 \\
Dextrin & 192 & 263 \\
Corn oil (ml) & 150 & 150 \\
Mineral mix & 40 & 40 \\
Choline chloride (50\%, wt) & 4 & 4 \\
$\quad$ vol) (ml) & & \\
Cellulose & 35 & 35 \\
Vitamin mix $\dagger$ & 10 & 10 \\
Methionine & & 1.0
\end{tabular}

\footnotetext{
* Rogers-Harper Mineral Mix (Teklad Test Diets, Madison, WI).

† AIN Vitamin Mixture 76 (ICN Pharmaceuticals, Inc., Cleveland,
} $\mathrm{OH})$. was significantly increased in the animals receiving caffeine $(6 \%$ + C). A small decrease was seen in normally nourished animals given caffeine compared to the noncaffeine group, but this decrease did not achieve statistical significance.

RNA per brain was significantly increased in the normally nourished groups compared to the malnourished groups (Table 4). Caffeine also produced a significant increase in RNA in both caffeine-supplemented groups when compared to their comparably nourished controls $(20 \%+\mathrm{C}>20 \% ; 6 \%+\mathrm{C}>6 \%)$. Expressed as mg RNA/g brain, significant differences were also seen in all above comparisons except $20 \%+C$ versus $6 \%+C$.

Total protein per brain was significantly greater in the $20 \%$ group compared to the $6 \%$ group (Table 4 ). Animals in the $20 \%$ $+\mathrm{C}$ group contained significantly more protein per brain and per gram of brain than the $20 \%$ group not given caffeine. This effect was seen, however, when $6 \%$ was compared to $6 \%+\mathrm{C}$. Protein per gram of brain was similar in the $20 \%$ group compared to the $6 \%$ group.

Brain cholesterol per brain and per gram of brain weight was not different among comparably nourished groups given caffeine (Table 4). The $20 \%$ group contained more cholesterol than the $6 \%$ group.

\section{DISCUSSION}

In an earlier study of the effects of theophylline (22) on the brains of newborn rats, we found that the nutritional condition of the newborn plays an important role in determining the effects of theophylline. The present study examines another xanthine derivative, caffeine, which is also used in the treatment of apnea in the neonate. The similarity in the body weight of the pups in the present study between the caffeine and noncaffeine groups, of both the 20 and $6 \%$ protein groups, was quite unexpected. Previously, when caffeine $(20 \mathrm{mg} / \mathrm{kg})$ was given to lactating dams, the body weight of the suckling pups was decreased in the $20 \%$ protein group and increased in the $6 \%$ protein group (19). If indirect caffeine intake by the pups during the lactating period is only $2 \%$ of the maternal caffeine intake, as reported (1), then theoretically the pups in the present study received much greater amounts of caffeine $(10 \mathrm{mg} / \mathrm{kg})$. It is conceivable that direct administration of a higher content of caffeine to the animals, once every $48 \mathrm{~h}$, might exert a different effect on somatic growth in the newborns compared to the continuous intake of less caffeine through the dam's milk. It is also possible that when

Table 3. Brain weights

\begin{tabular}{lc}
\hline \multicolumn{1}{c}{ Maternal diet } & Brain wt $(\mathrm{g})$ \\
\hline 20\% protein $(n=12)$ & $1.303 \pm 0.060^{*}$ \\
$20 \%$ protein + caffeine $(n=20)$ & $1.314 \pm 0.073^{*}$ \\
& $1.093 \pm 0.079^{*}$ \\
$6 \%$ protein $(n=13)$ & $1.107 \pm 0.077^{*}$ \\
\hline
\end{tabular}

* Significant differences $(p<0.05)$ due to nutrition $(20$ versus $6 \%$; $20 \%+C$ versus $6 \%+C)$. Data are mean \pm SD.

Table 2. Pup ages in days and weight in grams

\begin{tabular}{|c|c|c|c|c|c|c|c|c|}
\hline \multirow[b]{2}{*}{ Maternal diet } & \multicolumn{8}{|c|}{ Day of age } \\
\hline & 1 & 3 & 5 & 7 & 9 & 11 & 13 & 15 \\
\hline $\begin{array}{l}20 \% \text { protein }(n= \\
16)\end{array}$ & $7.23 \pm 0.64$ & $9.61 \pm 0.90$ & $13.38 \pm 1.47^{*}$ & $17.97 \pm 1.40^{*}$ & $22.69 \pm 1.65^{*}$ & $27.71 \pm 2.83^{*}$ & $32.50 \pm 2.38^{*}$ & $36.83 \pm 3.42^{*}$ \\
\hline $\begin{array}{l}20 \% \text { protein }+C \\
(n=16)\end{array}$ & $7.02 \pm 0.78$ & $9.39 \pm 1.5$ & $13.45 \pm 2.85^{*}$ & $17.86 \pm 2.70^{*}$ & $22.36 \pm 3.59^{*}$ & $27.87 \pm 3.72^{*}$ & $31.45 \pm 4.70^{*}$ & $38.70 \pm 5.10^{*}$ \\
\hline $\begin{array}{l}6 \% \text { protein }(n= \\
16)\end{array}$ & $6.85 \pm 0.74$ & $9.05 \pm 0.69$ & $11.07 \pm 1.21^{*}$ & $12.24 \pm 1.49^{*}$ & $14.05 \pm 1.92^{*}$ & $15.24 \pm 1.94^{*}$ & $16.35 \pm 2.03^{*}$ & $17.26 \pm 1.96^{*}$ \\
\hline $\begin{array}{l}6 \% \text { protein }+C(n \\
\quad=16)\end{array}$ & $7.34 \pm 0.34$ & $9.01 \pm 0.54$ & $10.93 \pm 0.48^{*}$ & $12.73 \pm 0.84^{*}$ & $14.21 \pm 1.43^{*}$ & $15.53 \pm 1.45^{*}$ & $16.75 \pm 1.49^{*}$ & $17.51 \pm 1.53^{*}$ \\
\hline
\end{tabular}

\footnotetext{
* Significant difference $(p<0.05)$ due to nutrition $(20$ versus $6 \% ; 20 \%+$ C versus $6 \%+C)$. Data are mean \pm SD.
} 
caffeine is administered to the lactating dam, changes in mothering behavior may occur which are different from that in nontreated dams. Drug concentration in milk may be altered by malnutrition or the milk volume may be affected by the methylxanthine in the malnourished dams. None of these presumptive maternal effects would have been present in this study, since caffeine was given directly to the pups.

Caffeine exerts an effect on DNA synthesis in vitro $(20,24)$. In the present study, when the DNA (cell number) values are expressed as DNA per brain, the malnourished groups given caffeine synthesized more DNA than the noncaffeine group, whereas there was no such difference in the normally nourished groups. Just how protein energy malnutrition intensifies caffeine's effects on brain cell number is not known. However, it is possible that, since infants metabolize caffeine more slowly than adults (2), malnutrition may have further prolonged its biological half-life. It is also well known that protein-deficient states may intensify a drug's effects by retarding metabolic degradation and clearance $(12,14)$.

The total protein content was significantly greater in the $20 \%$ $+\mathrm{C}$ group compared to the noncaffeine group. Consistently greater values were also observed in the $6 \%+\mathrm{C}$ than in $6 \%$ without caffeine, but these differences were not statistically significant. Previously, we found that when the $6 \%$ protein diet with caffeine $(20 \mathrm{mg} / \mathrm{kg})$ is fed to the dam, the total protein in the brain of the suckling pups is increased (16). Brain protein in the $20 \%+\mathrm{C}$ is also greater than in $20 \%$, but was statistically insignificant (16). Caffeine has been previously shown to enhance protein synthesis (15). It seems then that effects of caffeine are influenced by the nutritional state of the subjects. Alternately, these results may be due to the caffeine effect perhaps acting through mechanisms not dissimilar to environmental stimulation as reported $(5,17)$. The effects attributable to caffeine would be another example of a complicated drug-nutrient interaction.

The average brain cell size (protein:DNA) calculated by the standard method $(7,28)$ in $6 \%+C$ was smaller compared to that of $6 \%$, but cell size in the control group given caffeine was greater than the comparably nourished controls. This trend is the same as is seen with theophylline supplementation (22). Thus, it seems that caffeine given to the growing pups affects the cell size differently than brain cell number, depending upon the nutritional status of the pups. This fact could be interpreted as cell hyperplasia, persisting at the expense of increased cell size in the presence of malnutrition and caffeine, while in the normally nourished groups, the increase in cell number induced by caffeine was accompanied by expected cell size increases.

Caution must be used in interpreting the average cell size per brain, which is measured by the protein:DNA ratio. The brain of the young rat is growing at different rates in different areas. Also, certain cell types are enlarging as they mature, while others may become smaller as they differentiate. Our data reflect the sum of all these processes.

The ratio of RNA to DNA, an index of cellular activity, was not different between theophylline and nontheophylline groups in both control and malnourished pups (22) in previous studies. But in the present study, caffeine was administered by a different route and produced a significant increase in cellular activity in both the $20 \%+C$ and $6 \%+C$ groups when compared to the other animals. This index was not affected by nutritional status.

Total brain cholesterol was also measured. Myelination in the rat brain occurs largely after 15 days of age. Cholesterol deposited up to 15 days is largely membranous. Caffeine in high doses has been shown to transiently decrease myelin synthesis in neonates (9). The present data show no difference in cholesterol deposition between caffeine and noncaffeine in the normal and malnourished groups. This indicates that caffeine intake does not seem to inhibit membrane-related cholesterol synthesis regardless of nutritional status.

Growing human newborns are frequently exposed to caffeine through various medications (10). Our current studies suggest 
that nutritional status of the newborn and, possibly, the route of administration are factors which may affect their brain development and their cellular response to exposure to caffeine. It is reported that the metabolic response to caffeine may be influenced by the route of administration of the individual substrate (23).

While interspecies extrapolations must be made with extreme caution, the growing amount of data from the animal model should lead the clinician to consider the nutritional status of the neonate when using methylxanthines.

The present data and our previous work with theophylline (22) indicate that methylxanthine administratioin the presence of a compromised nutritional status may exert long term effects on brain development. Further studies are needed to determine which areas of the brain are affected.

Acknowledgments. The authors wish to acknowledge the expert technical assistance provided by Mr. J. Morris, Ms. G. Young, Ms. D. Shew, and Mr. J. Laurent.

\section{REFERENCES}

1. Aeschbacher HU, Milon H, Pott A, Wurzner HP 1980 Effect of caffeine on rat offspring from treated dams. Toxicol Lett 7:71

2. Aldridge A, Aranda JV, Neims AH 1979 Caffeine metabolism in the newborn. Clin Pharmacol Ther 25:447

3. Aranda JV, Garnan W, Bergsteinsson H, Gunn T 1977 Efficacy of caffeine in the treatment of apnea in the low birth weight infant. J Pediatr 90:467

4. Block WD, Jarrett KJ, Levine JB 1966 An improved automated determination of serum total cholesterol with a single color reagent. Clin Chem 12:681

5. Cines BM, Winick M 1979 Behavioral and physiological effects of early handling and early malnutrition in rats. Dev Psychobiol 12:381

6. Dunlop M, Court JM, Larkins RG 1981 The effects of maternal carbohydrate (sucrose) supplementation on the growth of offspring of pregnant rats with habitual caffeine consumption. Biol Neonate 40:196

7. Enesco M, Lebond CP 1962 Increase in cell number as a factor in the growth of the young male rat. J Embryol Exp Morphol 10:530

8. Friedman L 1966 Nutritional status and biological response. Fed Proc 25:137

9. Fuller GN, Divakaran P, Wiggins RC 1978 The effect of postnatal caffeine administration on brain myelination. Brain Res 249:189

10. Graham DM 1978 Caffeine-its identity, dietary sources, intake and biological effects. Nutr Rev 36:97

11. Howell J, Clozel M, Aranda JV 1981 Adverse effects of caffeine in the newborn infant. Semin Perinatol 5:359

12. Lee NH, Hospador MA, Manthei RW 1967 Influence of age and dietary stress on hexabarbital activity in mice. Proc Soc Exp Biol Med 125:153

13. Lowry OH, Rosebrough NJ, Farr AL, Randall RJ 1951 Protein measurement with the Folin phenol reagent. J Biol Chem 193:265

14. Metha S, Kalsi HK, Jajaraman S, Mathur VS 1975 Chloramphenicol metabolism in children with protein-calorie malnutrtion. Am J Clin Nutr 28:977

15. Miyamoto E, Kuo JF, Greengard P 1969 Adenosine 3',5'-monophosphatedependent protein kinase from brain. Science 165:63

16. Mori M, Wilber JF, Nakamoto $T 1983$ Influences of maternal caffeine on the neonatal rat's brains vary with the nutritional states. Life Sci 33:2091

17. Morgan BLG, Winick M 1980 Effects of environmental stimulation on brain $N$-acetylneuraminic acid content and behavior. J Nutr 110:425

18. Nakamoto T, Miller SA 1977 Effect of protein-energy malnutrition on the growth of mandible and long bone in newborn male and female rats. J Nutr 107:983

19. Nakamoto T, Shaye R 1984 Effects of caffeine on the growth of mandible and long bone in protein-energy malnourished newborn rats. Proc Soc Exp Biol Med 177:55

20. Painter RB 1980 Effect of caffeine on DNA synthesis in irradiated and unirradiated mammalian cells. J Mol Biol 143:289

21. Prasad AS, Dumouchell E, Kovich D, Oberlear D 1972 A simple fluorometric method for the determination of RNA and DNA in tissues. J Lab Clin Med 80:598

22. Quinby GE, Nakamoto T 1984 Theophylline effects on cellular response in protein-energy malnourished neonatal rat brain. Pediatr Res 18:546

23. Rothberg AD, Marks KH, Ward RM, Maisels MJ 1981 The metabolic effects of caffeine in the newborn infants. Pediatr Pharmacol 1:181

24. Sivak A, Rudenko L, Teague LG 1982 Variations among species and cell types in the effects of caffeine on mutagen induced cytotoxicity and postreplication repair of DNA. Environ Mutat 4:143

25. Somani SM, Khanna NN 1981 Methylxanthine in serum saliva and spinal fluid of premature infants. Semin Perinatol 5:346

26. Turmen T, Davis J, Aranda JV 1981 Relationship of dose and plasma concentrations of caffeine and ventilation in neonatal apnea. Semin Perinatol 5:326

27. Varma DR 1979 Influence of dietary protein on the anti-inflammatory and ulcerogenic effects and on the pharmacokinetics of phenylbutazone in rats. J Pharmacol Exp Ther 24:338

28. Winick M, Noble A 1965 Cellular response in rats during malnutrition at various ages. Dev Biol 12:451 